\title{
EN BUSCA DE LA MEMORIA PERDIDA. LA GUERRA CIVIL Y LA FOTOGRAFÍA ESPAÑOLA CONTEMPORÁNEA
}

\author{
Antonio Ansón \\ Universidad de Zaragoza \\ aanson@unizar.es
}

\begin{abstract}
Este trabajo propone una revisión de la historia de la fotografía española del siglo XX tomando como referencia el posicionamiento de los artistas ante la memoria de la guerra civil y sus consecuencias. La postguerra, la transición política y la democracia determinan respuestas diferentes a un mismo trauma colectivo que se traduce en tres conceptos: Silencio, Olvido y Memoria.

Palabras clave: Historia de la Fotografía española; Guerra Civil Española; Silencio; Olvido; Memoria; Postguerra;
\end{abstract} Transición Política; Democracia; AFAL; Nueva Lente.

\section{IN SEARCH OF LOST MEMORY: THE SPANISH CIVIL WAR AND CONTEMPORARY SPANISH PHOTOGRAPHY}

This paper proposes reviewing the history of twentieth-century Spanish photography taking as its point of reference the positioning of artists vis-à-vis the memory of the Civil War and its consequences. The post-Civil War, the political transition and democracy engender different responses to shared collective trauma, resulting in three concepts: Silence, Forgetting and Memory.

Key words: Spanish Photography; Spanish Civil War; Silence; Forgetting; Memory; Post-Civil War; Politicial Transition; Democracy; AFAL; Nueva Lente.*

En los últimos años una serie de fotógrafos que rondan los cincuenta años han focalizado su trabajo en torno a la memoria sobre la guerra civil. Desde distintos puntos de vista, con diferentes planteamientos teóricos y estéticos, comparten como denominador común la necesidad de hacer suyos unos acontecimientos que han vivido de forma vicaria. La experiencia les llega como herencia no a través de sus padres, sino a través de sus abuelos. A qué se debe esa necesidad de ejercer una memoria mediante un artificio fotográfico, y por qué precisamente esa tercera generación de artistas y no sus predecesores en términos fotográficos. Esos fotógrafos de la Memoria no comparten una base programática, en muchos casos ni siquiera conocen la existencia unos de

* Este trabajo ha sido realizado en el marco del proyecto de investigación Estudio de la cultura audiovisual del tardofranquismo (1965-1975), referencia: HAR2013-45058-P, investigador principal: Amparo Martínez Herranz, Universidad de Zaragoza. Mi gratitud para Agustín Sánchez Vidal, Ana Teresa Ortega y Martí Llorens por su inestimable ayuda. 
otros, y sin embargo convergen en la reivindicación de la memoria frente al olvido. La guerra civil y sus consecuencias convertidas en el marchamo de importantes proyectos fotográficos al que han dedicado esfuerzos y empeño.

Nuestro trabajo se propone, pues, defender la tesis de una secuencialización de la historia de la fotografía española del siglo XX que tiene la impronta de la guerra civil como señas de identidad. Desde el final de la guerra civil hasta la actualidad se suceden tres generaciones de fotógrafos, nacidos en torno a 1940, 1950 y 1960, que se identifican con tres conceptos nítidamente delimitados: Silencio, Olvido y Memoria.

No obstante, hay que tener en cuenta que nuestro objetivo es proponer y explicar tendencias dominantes, y que esas tendencias dan siempre lugar a particularidades que se traducen en excepciones, sin que por ello quede invalidado el concepto general en su conjunto. En cualquier caso, como veremos a continuación, las líneas generacionales, estéticas e ideológicas, que proponemos tienen los suficientes elementos en común para comprender cual era la situación de la fotografía en el momento histórico en el que se manifiesta.

Esas tres etapas se corresponden con la postguerra, la transición y la democracia en España, y a modo de escenificación puede decirse que están protagonizadas por los padres, los hijos y los nietos que, de una forma u otra, son la consecuencia de un conflicto que ninguno vive de forma directa. Los primeros, los padres, se hacen hombres en plena dictadura y van a silenciarlo por razones obvias.

Esa primera generación franquista, "creció con este miedo a enterarse, a interesarse, a mostrar curiosidad. Creció sin pasado" , escribe Víctor Alba. En los hogares españoles, hasta bien entrados los años sesenta, cuando el franquismo había perdido ya el rigor primero, lo más importante era no significarse, no darse a entender, y callar. "Naturalmente -continúa escribiendo Víctor Albano conociendo las respuestas, esta generación, al llegar a la edad adulta, no pudo transmitir a sus hijos, a la enteramente franquista, ni valores, ni historia, ni experiencia. Ésta se limitaba a que callando y no preguntando se vivía con paz y tranquilidad". ${ }^{2}$

Los segundos, los hijos, crecen de espaldas a la guerra y miran fuera. Lo que quieren es olvidar, dejar atrás la caspa y el olor rancio para orientar sus miradas más allá de nuestras fronteras. La transición política y el olvido histórico se vuelven consignas para la supervivencia y el salto adelante que ha de convertir España y sus artistas en ciudadanos del mundo rabiosamente modernos. Desean salir, conocer, internacionalizarse, porque ya cuentan con los medios y la preparación. Curiosamente, corresponde a la tercera generación, la de los nietos, el papel de recordar una herida que sus abuelos se vieron obligados a callar y que sus padres decidieron enterrar en los sótanos de la memoria.

Se trata de acercarse y comprender una doble pregunta: ¿por qué las dos primeras generaciones de fotógrafos, los del Silencio y el Olvido, no se asomaron desde sus trabajos a lo que acababa de ocurrir o estaban padeciendo, y por qué es la tercera generación, la de los nacidos en torno a 1960, quienes demuestran un interés constante y cargado de emoción por los protagonistas, sus acciones y las consecuencias de la guerra? De manera simbólica, el expresidente del gobierno José Luis Rodríguez Zapatero, nacido no por casualidad en 1960, ejemplifica este interés hasta entonces tibio cuando no arrinconado, tal vez latente, con la promulgación de una ley de la memoria histórica y su elocuente recuerdo al abuelo militar, fusilado durante la guerra civil.

La generación del Silencio cuenta como portavoz privilegiada la revista almeriense AFAL. Por su parte, la generación que le sigue pone en escena su olvido y su apuesta por la modernidad a través de la revista Nueva Lente. La generación de la Memoria no responde a un grupo de fotó-

\footnotetext{
${ }^{1}$ Alba, 1980: 45

2 Alba, 1980: 45.
} 
grafos organizados de forma programática y en torno a una publicación específica, sino que actúan de manera independiente y casi siempre sin contactos entre unos y otros, aunque coincidan en una misma necesidad reivindicativa donde el objetivo consiste en actualizar y restituir el dolor acallado de las víctimas.

La generación del Silencio está compuesta por unos fotógrafos que, a excepción de Paco Gómez, que tiene dieciocho años al estallar la guerra, se sitúa en los umbrales de la adolescencia o son apenas niños: Joan Colom y Catalá Roca han cumplido catorce, Gonzalo Juanes trece y Cualladó once. El resto, Masats, Maspons, Francisco Ontañón, Pérez Siquier, Schommer, Virxilio Vieitez, son unos niños. Miserachs nace en 1937.

Salvo Julio Ubiña y Schommer, que tienen desde un principio un contacto profesional con la fotografía, y casos como Masats que se traslada a Madrid para trabajar como fotorreportero, el resto comienzan su andadura como fotógrafos aficionados que se ganan la vida con actividades profesionales que nada tienen que ver con la fotografía (empleados de banca, profesores, agentes de seguros, médicos o negocios propios) y sólo muy recientemente verán reconocido su trabajo y hasta se sorprenderán al sentirse ascendidos a la categoría de artistas. Como bien recoge Horacio Fernández en Variaciones en España (1900-1980), "no tenían la menor intención de hacer arte, una palabra gastada por los pretenciosos fotógrafos aficionados de las sociedades"”3 (fotográficas, se entiende), sin que por ello renunciaran a una curiosidad por todo cuanto sucedía en el mundo de la fotografía, dentro de las limitaciones impuestas por la autarquía cultural, y reivindicando desde el foro de la revista AFAL propuestas del todo innovadoras con respecto al salonismo imperante, que aglutinó las inquietudes y el debate estético que estaba presente en las inquietudes de todos ellos.

Se repite en las historias de la fotografía, como un lugar común, el carácter reivindicativo de la fotografía española de los años cincuenta atribuyéndole el calificativo de neorrealista, asimilándolo tanto en estética como en intención con el movimiento cinematográfico italiano inmediatamente posterior a la Segunda Guerra Mundial. Enric Mira afirma en La vanguardia fotográfica de los años sesenta en España refiriéndose a los orígenes de AFAL como plataforma del primer documentalismo social que:

una de las motivaciones claves en la génesis de este impulso fue la decepción surgida ante el agotamiento de la poética pictorialista que abarrotaba el pequeño mundo del salonismo de la posguerra. Frente a aquella visión ilusoria de una realidad hecha a golpe de idealizados prototipos, colmados de belleza, se volverá la cámara hacia lo cotidiano, lo vulgar y lo gastado, la fotografía era el medio idóneo para documentar verazmente y sin esteticismo la realidad de una España rural y pobre. Este punto de partida crítico hizo concebir dicha fotografía como un modo de denuncia social. ${ }^{4}$

Y más adelante justifica este análisis argumentando que "comunicar es dar testimonio de una realidad que generalmente se descubre como injusta o inhumana, por ello los temas sórdidos son uno de los motivos de denuncia preferidos por la fotografía neorrealista. Y, sobre todo, el acto de comunicar fotográfico va a suponer, como exigencia de los anterior, una actitud de compromiso social por parte del fotógrafo"s.

Si repasamos los trabajos realizados por estos fotógrafos en la década de los cincuenta observamos efectivamente un retrato de la pobreza, aunque sin una intención de denuncia social, e incluso en ocasiones con una pincelada que pone el acento en lo pintoresco. De forma excepcional, el trabajo fotográfico que Carlos Saura lleva a cabo durante el rodaje de Carta de Sanabria, en el

\footnotetext{
${ }^{3}$ Fernández, 2004: 120.

${ }^{4}$ Mira, 1991: 32.

5 Mira, 1991: 36.
}

Arch. esp. arte, LXXXIX, 354, ABRIL-JUNIO 2016, 153-166

ISSN: 0004-0428, eISSN: 1988-8511, doi: 10.3989/aearte.2016.10 
que participa como ayudante de dirección de Eduardo Ducay, contiene una mayor dosis de visión analítica y de exposición cruda de la realidad, prescindiendo de todo atisbo de preciosismo formal para subrayar la dureza vital que expresan los personajes retratados y que, como indica Agustín Sánchez Vidal, nos remiten directamente a Las Hurdes. En el texto que Mar Alberruche Rico dedica a la fotografía española de postguerra y donde perfila de manera acertada el concepto de "fotografía pauperista" acuñado por Juan Antonio Ramírez, más adecuado que el de neorrealista, señala que "a diferencia del resto de autores, la fotografía "pauperista" de Saura sí está concebida como un documento de denuncia", a lo que hay que añadir que debe tenerse en cuenta para todos ellos la ambivalencia entre intención y repercusión, es decir, la visión de Saura y la intención del resto tuvo una difusión más que restringida.

Rafael Doctor vuelve a repetir, refiriéndose a la generación AFAL "que realizaron un trabajo compacto y acorde con las corrientes exteriores neorrealistas" " "La fotografía de AFAL - escribe Marie-Loup Sougez citando a Pérez Siquier- ofreció en su momento una producción subversiva en la medida en que retrataba a la sociedad española en su realidad cotidiana. Constituían una corriente humanista que denunciaba los problemas sociales, el peso del autoritarismo gubernamental y eclesial, con tintes de humor, rozando a veces el esperpento"8. En su Historia general de la fotografía subraya igualmente la "política de denuncia" de AFAL. Sin embargo, mucho más ajustada nos parece su intervención en los encuentros que sobre Nueva Lente tuvieron en 1993, donde señala que "a posteriori se da un marchamo de politización o de voluntad de reflexión o de rebeldía a una gente que en aquella época no tenía ningún color, que no estaba satisfecha con el ambiente, con la sociedad, pero que en realidad buscaba una salida sin saber muy bien de qué manera" ${ }^{\text {" }}$.

En la exposición organizada por Steichen The Family of Man, que tanto dio que hablar en el grupo de fotógrafos que aglutinó AFAL, tampoco existe ninguna intención de denuncia o reivindicación social. Del mismo modo, la fotografía humanista francesa de posguerra, de la que igualmente se hizo eco AFAL, carece de cualquier dimensión combativa en términos sociales. Existe desde luego un valor testimonial y un reconocimiento de la realidad de las calles con un componente altamente estético, si bien la mirada está desprovista de intención de denuncia.

En algunos momentos pueden reconocerse ciertos rasgos de la estética neorrealista porque los motivos fotográficos reflejan la pobreza, los terrenos baldíos y los descampados que aparecen en las películas neorrealistas italianas, atmósfera muy similar a la que pone en escena con toda crudeza social y moral Surcos, de José Antonio Nieves Conde. Lo que los fotógrafos muestran en sus imágenes es la España paupérrima de la posguerra, muy lejos del tenebrismo de Eugène Smith en Spanish Village de 1950, o la violencia contenida que encierran las instantáneas tomadas en España por Cartier Bresson antes y después de la guerra, con un tinte solanesco y brutal que en ningún momento puede reconocerse en los trabajos del grupo de fotógrafos de AFAL.

Puede decirse que la fotografía española de los años cincuenta recuerda la estética neorrealista, pero no su contenido. En este sentido compartimos la opinión que Laura Terré ${ }^{11}$ dedica a la cuestión en su extenso y detallado estudio sobre AFAL, dejando clara la ausencia de la huella neorrealista durante este periodo de la fotografía española. "En vez de intentar transmitir significados y conocimientos sobre la sociedad para participar en su transformación -escribe al respecto Horacio Fernández- los nuevos fotógrafos de los años cincuenta se conformaban con conocerla. Les interesaban los aspectos menos perfectos de las cosas y la gente. La causa de su curiosidad y la

\footnotetext{
${ }^{6}$ Alberruche, 2010: s.p.

Doctor, 1995: 19.

${ }^{8}$ Sougez, 2011: 447.

${ }^{9}$ Sougez, 2007: 528.

${ }^{10}$ Sougez, en Doctor, 1995: 120.

11 Terré, 2006: 67-75.
} 
fuente de sus tomas fotográficas era el mundo cotidiano, ante el que no era raro que reaccionaran con la incomprensión y la irracionalidad que caracterizaba las ideas culturales de su época, como el existencialismo filosófico y literario, la pintura gestual y otros pesimismos envueltos en música de jazz fría y distante" 12 .

No hay rastro de denuncia social porque sencillamente no se podía, y mucho menos cualquier alusión a la guerra civil y sus consecuencias. "Quien no haya vivido los primeros años del franquismo - anota de forma testimonial Víctor Alba- no puede imaginar lo que fue el miedo" "13 "y el primer resultado de miedo - añade más adelante- fue el silencio" ${ }^{\prime 14}$. Podemos imaginar lo que hay detrás de esas imágenes de estética neorrealista, intuir la desolación moral y material, pero no podemos verla. Las preocupaciones y las inquietudes del grupo de fotógrafos que aglutina AFAL son de otra índole: hacerse eco de las corrientes novedosas europeas y americanas y reivindicar, ahora sí, unos presupuestos estéticos novedosos ante el correoso salonismo imperante desde la plataforma de la revista, o llanamente sobrevivir con la profesión de fotógrafos para algunos de ellos, que no es poco. La historia visual española de los años cincuenta es una crónica del silencio. Se trata de una fotografía silenciada en una sociedad silenciada. La novela de Luis Martín Santos Tiempo de silencio, publicada en 1962, o uno de los capítulos cinematográficos que componen Nueve cartas a Berta (1966) de Basilio Martín Patino, también con el mismo título, sirven de metáfora para ilustrar el espíritu y la letra de aquella época puesta en imágenes.

La segunda generación, salvo excepciones, nace en torno a los años cincuenta. Ya no son aficionados ni ejercen la fotografía en el tiempo libre que les permiten sus trabajos de empleados de banca o comerciantes. Tienen formación universitaria, en muchos casos en Bellas Artes, Ciencias de la Información, Historia del Arte. La generación Nueva Lente ya no aspira a ser fotógrafos, sino a ser artistas, y de manera profesional, y en muchos casos lo van a conseguir alcanzando una proyección internacional hasta entonces impensable.

La fotografía española de los setenta tiene puestas las miras más allá de nuestras fronteras. Viajan con regularidad a Arles, donde dan a conocer sus trabajos en el emblemático festival de fotografía, del que Joan Fontcuberta será su director artístico en 1996, exponen sus trabajos en museos y galerías de toda Europa y Estados Unidos. Son los primeros artistas de la democracia. Su estética ya no es documentalista, como sucede con la generación precedente, sino que sus inquietudes son más bien de carácter estético: los dípticos de Rafael Navarro, los fotocollages de Jorge Rueda, el discurso ficcional de Joan Fontcuberta, llevado a cabo junto a Pere Formiguera con la narración de Fauna. El erotismo, el sexo, los cuerpos explícitos de Miguel Oriola. España cambia el blanco y negro de la posguerra por un país de colorines, un Madrid democrático y castizo de tonos verbeneros y flashes en la noche que se hizo internacional que tan bien retrató Pablo Pérez Mínguez. Son los esperanzados y felices setenta, los de la movida, los de que España ya no es diferente sino mejor. La realidad en general y la de España en particular ha cedido paso a la práctica artística como reflexión que abraza la problemática cultural occidental desde su historia del arte. La generación Nueva Lente prefiere estrellarse conceptualmente contra un muro de ladrillos (Jordi Benito) ${ }^{15}$ o jugar a un rompecabezas para un público intelectual y preparado (Luis Gómez Escolar y Pablo Pérez Mínguez) ${ }^{16}$, con el objeto final de huir mediante una estética Pop de "una situación que podría, en una palabra, ser definida como rancia", escribe Carlos Serrano ${ }^{17}$. La grisura, la precariedad, la falta de información, el silencio, han quedado atrás, y se han

\footnotetext{
${ }^{12}$ Fernández 2004: 120.

13 Alba, 1980: 39.

14 Alba, 1980: 43.

${ }^{15}$ Nueva Lente, $\mathrm{n}^{\circ} 13,1973$ : 56-57.

${ }^{16}$ Nueva Lente, $\mathrm{n}^{\circ}$ 9, 1972: 23, 25.

${ }^{17}$ Nueva Lente, $\mathrm{n}^{\circ}$ 4, 1972: 13.
}

Arch. esp. arte, LXXXIX, 354, ABRIL-JUNIO 2016, 153-166

ISSN: 0004-0428, eISSN: 1988-8511, doi: 10.3989/aearte.2016.10 
propuesto olvidarlo con todas sus fuerzas, tal vez como una forma de supervivencia, de órdago al futuro, del mismo modo que sus predecesores guardaron silencio como un modo de sobrevivir igualmente al tiempo que les había tocado en suerte. Olvidar para vivir, la guerra y sus consecuencias, que ni se nombran, ni preocupan, ni importan ahora.

Los intereses de la generación fotográfica Nueva Lente tienen un carácter estético. Incluso las imágenes más rabiosamente irreverentes encierran una intención de rebeldía que supera el espacio local para sumarse a las corrientes contraculturales dominantes en la cultura occidental del momento. Tampoco en el relevo fotográfico de Nueva Lente existe un compromiso social y político con la situación que vive el país, y mucho menos el menor rastro que recuerde o señale nada que tenga que ver con la guerra civil. "La actitud de vanguardia mantenida desde Nueva Lente -analiza con acierto Enric Mira- se modela absolutamente desideologizada, desde el punto de vista político, en un país que estaba viviendo un momento de crisis política"18. La transición política española y la transición fotográfica comparten una misma voluntad de olvido premeditado. De la noche a la mañana el país, sus políticos y sus artistas se suben al tren de la modernidad, algunos en marcha, para viajar sin interrupciones hacia la fiesta de la democracia. Estos fotógrafos abandonan el documentalismo precedente apostando fuerte por una carrera artística plena. Comparten, en este sentido, "una actitud que conecta directamente con el espíritu cosmopolita de Nueva generación que, sin constricciones valorativos en exceso supeditadas al circuito nacional o local, toma el panorama internacional como sólida referencia para dotarse de una amplia perspectiva crítica" $" 19$ añade Enric Mira.

Hay que esperar a la Ley 52/2007 de 26 de diciembre, aprobada por el gobierno de José Luis Rodríguez Zapatero, para normalizar una inquietud que va más allá de la fotografía y de la que desde años antes se hacen eco, mediante diferentes declinaciones, los trabajos de un conjunto de fotógrafos que forman parte de la generación de la Memoria. En su mayoría han nacido en torno a los años sesenta, y tienen un conocimiento vicario de la guerra civil que han heredado, no de sus padres, sino de sus abuelos, transmisión que ha tenido lugar, además, de forma soterrada y precaria. Esa sea, tal vez, una de la razones que explican esa necesidad perentoria de dar visibilidad a un sentimiento que se materializa de múltiples formas, pero todas ellas con una voluntad de restitución.

"Es la hora, así, -dice la ley-de que la democracia española y las generaciones vivas que hoy disfrutan de ella honren y recuperen para siempre a todos los que directamente padecieron las injusticias y agravios producidos, por unos u otros motivos políticos o ideológicos o de creencias religiosas, en aquellos dolorosos períodos de nuestra historia. Desde luego, a quienes perdieron la vida. Con ellos, a sus familias. También a quienes perdieron su libertad, al padecer prisión, deportación, confiscación de sus bienes, trabajos forzosos o internamientos en campos de concentración dentro o fuera de nuestras fronteras. También, en fin, a quienes perdieron la patria al ser empujados a un largo, desgarrador y, en tantos casos, irreversible exilio. Y, por último, a quienes en distintos momentos lucharon por la defensa de los valores democráticos".

La generación de la Memoria son los últimos en tener una conciencia directa de la dictadura, pues asisten a la muerte de Franco en los umbrales de la adolescencia, con los años suficientes para saber, ajenos sin embargo al mar de fondo político y social que se está fraguando, más preocupados, todavía, en los asuntos del amor a la salida del colegio. Asisten, por otra parte, como convidados de piedra al nacimiento de la democracia, pues todavía no tienen edad suficiente para acudir a votar en las primeras elecciones. Cuatro años más tarde, la primera generación de la democracia que acudirá a las urnas tendrá conocimiento de la dictadura a través de los libros de historia y la experiencia directa del franquismo habrá terminado.

\footnotetext{
${ }^{18}$ Mira, 1991: 64.

19 Mira, 1991: 69.
} 
El primero en abordar en 1997 la cuestión de la guerra civil desde la fotografía, y con la particularidad de tratarse de un acercamiento desde lo creativo-ficcional, es Martí Llorens con su trabajo Memorias revolucionarias. En 2004 Monserrat Soto realiza la video-instalación Secreto 1. Las fosas comunes de la guerra civil española, incluido en su proyecto Archivos de archivos, y en 2006 aparece el libro de Sofía Moro Ellos y nosotros. A partir de esta misma fecha, el fotógrafo Pedro Pérez Esteban produce al alimón con el escritor José Giménez Corbatón, tres libros relacionados con la guerra civil: Cambriles (2006), Morir al raso (2009) y Memoria difusa (2011). La aprobación de la Ley de memoria histórica da el pistoletazo de salida a un conjunto de trabajos que abordan la cuestión desde diversas ópticas: Dark is the Room Where We Sleep (2007-2008), de Francesc Torres, Cartografias silenciadas (2007) de Ana Teresa Ortega, Socius (2008-2010), de Adrián Alemán, Forats de bala (2009) de Ricard Martínez, la exposición y libro de entrevistas Ejercicios de memoria (2011) a cargo de Juan Vicente Aliaga, Desaparecidos (2011) de Gervasio Sánchez, Desvelados (2011) de Clemente Bernad, y recientemente, en julio de 2014, Alexis W dedica su ventana indiscreta a los desaparecidos durante la guerra civil.

Martí Llorens lleva a cabo en Memorias revolucionarias (1997), publicado en forma de libro por la editorial Mestizo dos años más tarde, un doble salto mortal. Doble salto por doble reescritura, en el sentido de que, por un lado, ha dedicado buena parte de su trabajo y su entusiasmo de investigador fotográfico a una guerra civil que conoce y le emociona por el relato que le llega dos generaciones más allá. Su memoria, por tanto, es una memoria prestada y reinventada, vuelta materia gráfica de su propio relato personal. El segundo salto al vacío en Las memorias revolucionarias de Martí Llorens consiste en superponer un imaginario a otro imaginario, pues lo que Llorens retrata y propone como fotografías documentales de la guerra civil, adecuadamente positivadas y asimiladas a materiales fotográficos antiguos, no son otra cosa que instantáneas tomadas durante el rodaje en Barcelona de Libertarias (1996) de Vicente Aranda. La memoria de Martí Llorens es un constructo cuya finalidad es explicar y dar sentido, y no le resta validez ni autenticidad pues en el fondo responde a la necesidad de recuperar un espacio perdido que ahora se encarna, nunca mejor dicho, es decir, toma forma y cuerpo, visibilidad, en los soportes fotográficos que Llorens fabrica sin otro propósito que el de comprender el presente visualizando un pasado más soñado que vivido (fig. 1).

Incluido en su proyecto Archivos de archivos (1998-2006) Monserrat Soto realiza la video-instalación Secreto 1. Las fosas comunes de la guerra civil española (2004). En el catálogo que acompañó la exposición en Centre d'Art la Panera (2006) aparecen algunas fotos documentando la exhumación de la tumba y algunos retratos de los familiares que aportan su testimonio. Una vez más se repite el salto generacional que se vuelve principio activo y desencadenador: este Secreto 1 arranca con una carta de la propia Monserrat Soto dirigida a la Asociación para la recuperación de la memoria histórica solicitando información sobre su abuelo, supuestamente enterrado en la fosa común de Villamayor de los Montes. La video-instalación renuncia a un planteamiento documental apostando por una estética que escenifica mediante el recurso del chache e imágenes fijas sepia la fantasmagoría de la memoria. Las voces en off de los hijos de Pablo Pérez Cuesta, y abuelo de Monserrat Soto, reconstruyen la historia. A modo de estribillo visual el retrato de una de las hijas, Máxima, madre de la autora, primero de espaldas, acostada en la tierra de la fosa y por fin de frente, va pautando la sucesión de imágenes hasta el final. Previamente y a modo de colofón, una voz recita un sencillo poema que repite como un eco luctuoso, "estas son las fosas del silencio". La video instalación se cierra sobre con el retrato frontal de Máxima que mira a cámara en silencio.

Ellos y nosotros (2006) es el resultado de un ambicioso trabajo de Sofía Moro que se prolonga a lo largo de diez años donde alterna en contrapunto y por primera y única vez vencedores y vencidos. Cada uno de ellos posa para un sobrio retrato acompañados de emotivos testimonios que contextualizan y proponen una visión de la guerra desde ambos lados de la trinchera. No es casualidad que la autora aluda también en el prólogo a su abuelo a modo de germen de su interés

Arch. esp. arte, LXXXIX, 354, ABRIL-JUNIO 2016, 153-166

ISSN: 0004-0428, eISSN: 1988-8511, doi: 10.3989/aearte.2016.10 


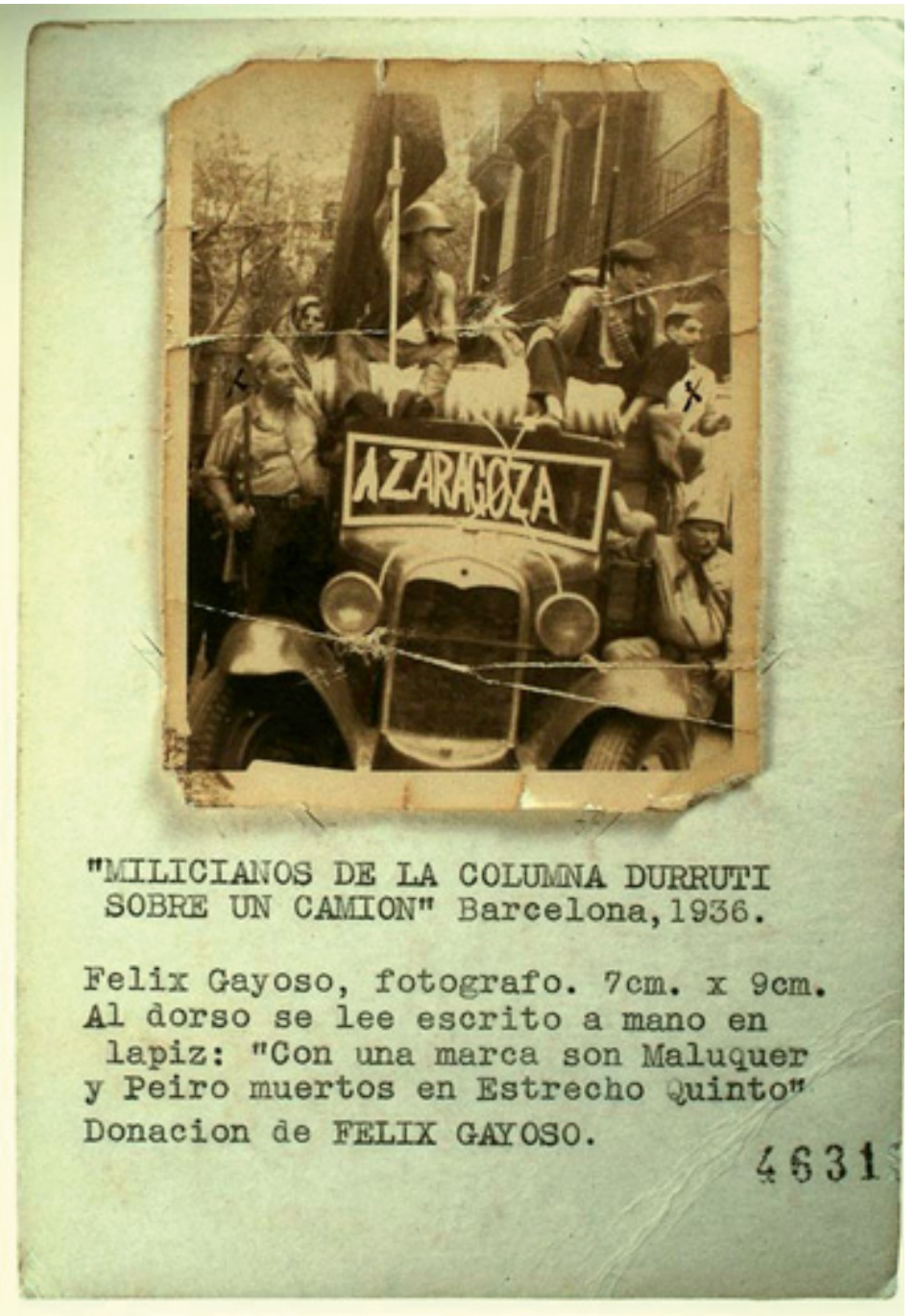

Fig. 1. Martí Llorens, Memorias revolucionarias (1997).

por el tema, que participó en una guerra, dice, de la que nunca se hablaba en casa. El propio título hace referencia a la doble visión de la narración en las voces de vencidos y también de vencedores, proponiendo una distancia en la exposición que subraya todavía más si cabe las emociones de sus protagonistas y la desmesura del enfrentamiento armado. El libro Ellos y nosotros es único en el género pues reúne en un mismo espacio el testimonio oral de todos los que hicieron la guerra, de los que la perdieron, y de los que la ganaron.

El fotógrafo Pedro Pérez Esteban, junto con el escritor José Giménez Corbatón, son los autores de tres libros dedicados a la guerra civil. Cambriles (2006) es un trabajo de corte periodístico sobre un grupo de hombres que buscan refugio en esta cueva mítica huyendo de la amenaza roja, donde constituyen la "Sociedad de la Caverna" que da cobertura a los topos destinados a conspirar desde el lado republicano. Morir al raso (2009) y Memoria difusa (2011) tiene un carácter más creativo. Pérez Esteban ofrece un recorrido fotográfico por los paisajes de la contienda centrando la atención de la mirada en detalles, grafitis y objetos que cumplen la función de silenciosos fetiches 
bélicos. Ambos libros se completan con la sugerente aportación literaria de Giménez Corbatón que pone la banda sonora en este tándem de la memoria de la guerra.

Dark is the Room Where We Sleep (2007-2008), de Francesc Torres, documenta la exhumación de una fosa común de fusilados durante la guerra civil en el pueblo burgalés de Villamayor de los Montes. Se plantea como una instalación con fotografías y una vitrina que contiene de forma simbólica un reloj que fue enterrado con uno de los fusilados. Francesc Torres compagina la herramienta documental de la fotografía, registrando el proceso de excavación con primeros planos de una bala y vistas generales de los familiares reunidos junto a la fosa, con el valor metonímico del objeto-tiempo del reloj emplazado simbólicamente a modo de recordatorio de un tiempo detenido y no recuperado pero sí hecho presente y tal vez restituido. El conjunto cobra una dimensión de santuario, cuyo centro y altar es el tiempo detenido y rehabilitado que encarna el reloj, motivo para el recogimiento.

Como la propia autora señala, "Cartografias silenciadas pretende dar visibilidad a los espacios más emblemáticos de la represión: campos de concentración, colonias penitenciarias militarizadas, y espacios donde hubo fusilamientos masivos durante la guerra civil y la postguerra". La manera de fotografiar esos espacios por Ana Teresa Ortega se plantea desde la afonía. Cada espacio queda actualizado en una especie de mutismo elocuente, como si la única respuesta posible ante la memoria doliente condujera a la suspensión de la palabra. Fotografiar sin añadir ni quitar nada, sin decir nada. La pulcritud técnica con la que están resueltas las imágenes, los encuadres austeros, la belleza de espacios despoblados y vacíos, fríos, traslucen una respiración sobrecogida, como la que el espectador experimenta ante un acontecimiento extraordinario que no se puede narrar ni remitir, sólo ver.

Adrián Alemán con su trabajo Socius (2008-2010) persigue superponer pasado y presente para dar sentido a uno y otro, porque sólo en esa confusión visual de las imágenes es posible entender el sentido y significado profundo de aquello que representan y que al mismo tiempo trascienden. Una aparente visión de calma y tranquilidad sobre la fosa de San Andrés en Tenerife esconde una de las mayores tragedias acaecidas durante la guerra civil, lugar al que fueron a parar cientos de ajusticiados entre los meses de julio de 1936 y febrero de 1937 (fig. 2).

Las imágenes corresponden a la misma toma realizada siempre desde el mismo punto a modo de ojo testimonial y neutro. Socius informa de la banalidad del dolor. Los paisajes marítimos e idílicos son la tarjeta postal del horror. En ningún lugar se manifiesta de forma más descarnada y aterradora el espanto como en la normalidad de las cosas. Un mismo punto de vista por el que circulan y desplazan barcos y estaciones, atardeceres y albas y noches de muerte. Si hay un rasgo que caracteriza e identifica el trabajo de Adrián Alemán es el de la contención. Sus fotografías reflejan una enorme mesura, y el espectador las contempla tan sobrecogido como emocionado tanto por lo que muestran como por lo que intuye que pueden esconder. Se trata de una invitación más que una demostración explícita, de ahí la fuerza y la tensión que subyace en cada una de las imágenes.

Forats de bala (2009) de Ricard Martínez se propone, mediante la identificación, reproducción a escala 1:1 y emplazamiento en los mismos lugares donde tuvieron lugar, algunas de las fotografías más emblemáticas de Agustí Centelles tomadas durante los combates en las calles de Barcelona. Los peatones circulan junto a las imágenes de manera simbólica. A modo de memento, las instantáneas de Centelles reinterpretadas por Ricard Martínez superponen el tiempo presente de los transeúntes al presente de los combates en las mismas calles que de forma cotidiana recorren ajenos a lo que allí ocurrió. Acontece una especie de palimpsesto temporal que las fotografías, jugando con la perspectiva en su colocación para confundirse con los escenarios del pasado y del ahora, ponen en escena. La acción aparece así atravesada en una lectura vertical que sincroniza los planos espacio-temporales actualizando la historia y reenviando el presente de los ciudadanos a un pasado latente en sus esquinas (fig. 3).

En 2011 Juan Vicente Aliaga organiza para el Centre d'Art la Panera una exposición que muestra algunos de los trabajos aquí ya comentados, junto al de otros artistas que, de una u otra forma,

Arch. esp. arte, LXXXIX, 354, ABRIL-JUNIO 2016, 153-166

ISSN: 0004-0428, eISSN: 1988-8511, doi: 10.3989/aearte.2016.10 


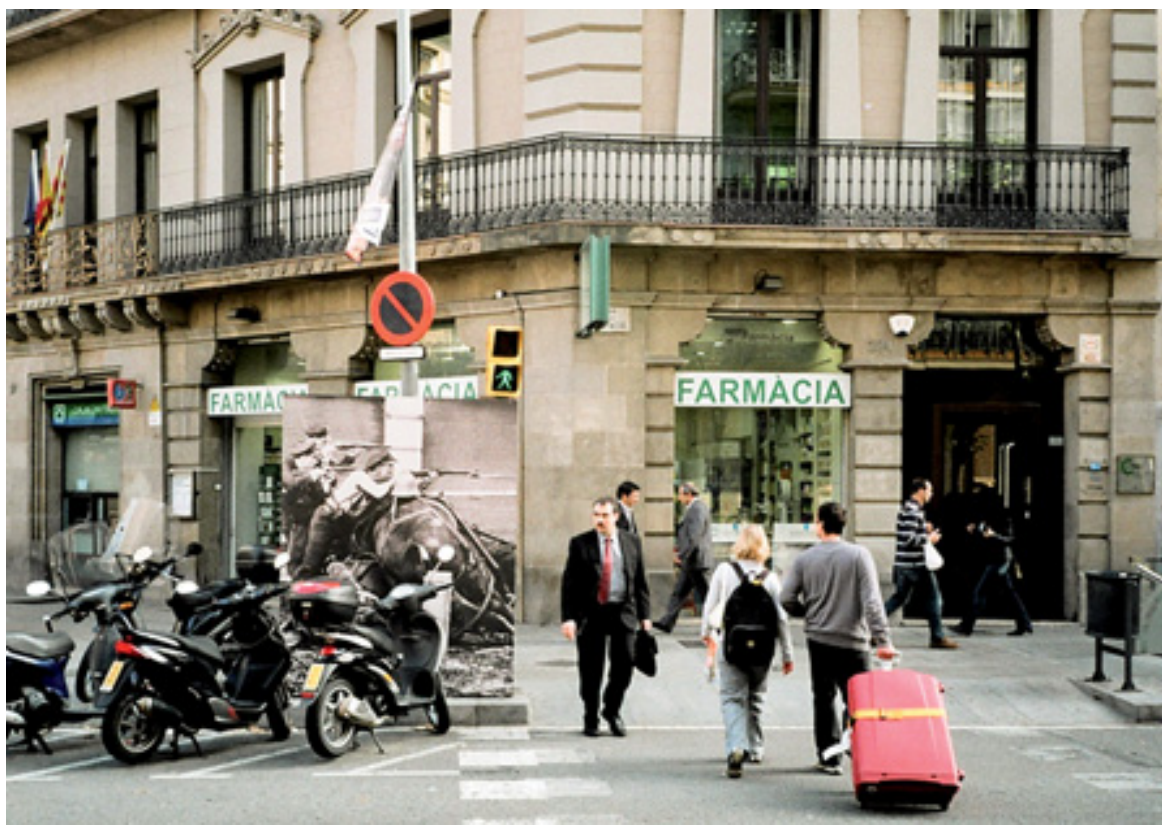

Fig. 2.

Ricard Martínez, Forats de bala (2009).

se suman a la tarea de redimir la memoria de la guerra civil. Las obras de Francesc

Abad, Joan Brossa, Marcelo Expósito, Rogelio López Cuenca, Ana Navarrete, Pedro G. Romero, María Ruido, Fernando Sánchez Castillo, combinan la instalación con una voluntad documental que incide en la represión sobre los vencidos, y tiene la crónica familiar como origen de la necesidad de salvar y decir su denominador común.

El trabajo de Gervasio Sánchez en Desaparecidos (2011) engloba la problemática de la violencia desde un planteamiento que agrupa testimonios e imágenes procedentes de América Latina, Asia y Europa, escenarios de conflictos armados, dedicando algunos de esos testimonios a desaparecidos durante la guerra civil española. Cada víctima posa ante la cámara de manera sobria sujetando en las manos el retrato del familiar desaparecido. Mediante el lenguaje del fotoperiodismo, Gervasio Sánchez no sólo muestra sino que reivindica el derecho de los familiares a saber. Los retratos y grabaciones dan voz a la huella de la violencia que se manifiesta en el ejercicio de la memoria.

Con Desvelados (2011), Clemente Bernad recorre y documenta las exhumaciones de un considerable número de fosas repartidas por distintos lugares de España. Se trata de diferentes espacios, diferentes fosas y diferentes familiares, pero se trata siempre de la misma fosa y de similar emoción compartida. La puesta en página no sigue ni orden cronológico ni tampoco una agrupación geográfica, sino que la crónica se presenta como una única narración que sucede en el presente gráfico del libro abierto al lector. La elección de imprimir las imágenes a sangre ayuda a crear un espacio que envuelve al espectador y lo sumerge intensificando el contenido de las imágenes y la presencia de los familiares. La diégesis se articula en la alternancia de tomas del proceso de exhumación y detalles encontrados con la reacción de las familias que asisten a los trabajos de excavación. La atmósfera final conseguida es espesa, tachonada con tomas generales que casi se convierten en paisajes concediendo un respiro a la narración. Primerísimos planos de restos y cráneos boquiabiertos se repiten a modo de estribillo lúgubre. La crudeza de algunas imágenes, los huesos de una mano que todavía sostienen su alianza, otra mano más adelante sujetando un antiguo retrato impreso en cerámica, quedan dulcificadas gracias a una pulcra presentación estética. Las protagonistas del dolor son en su mayoría mujeres de mirada ausente, en pié junto a la fosa o acu- 


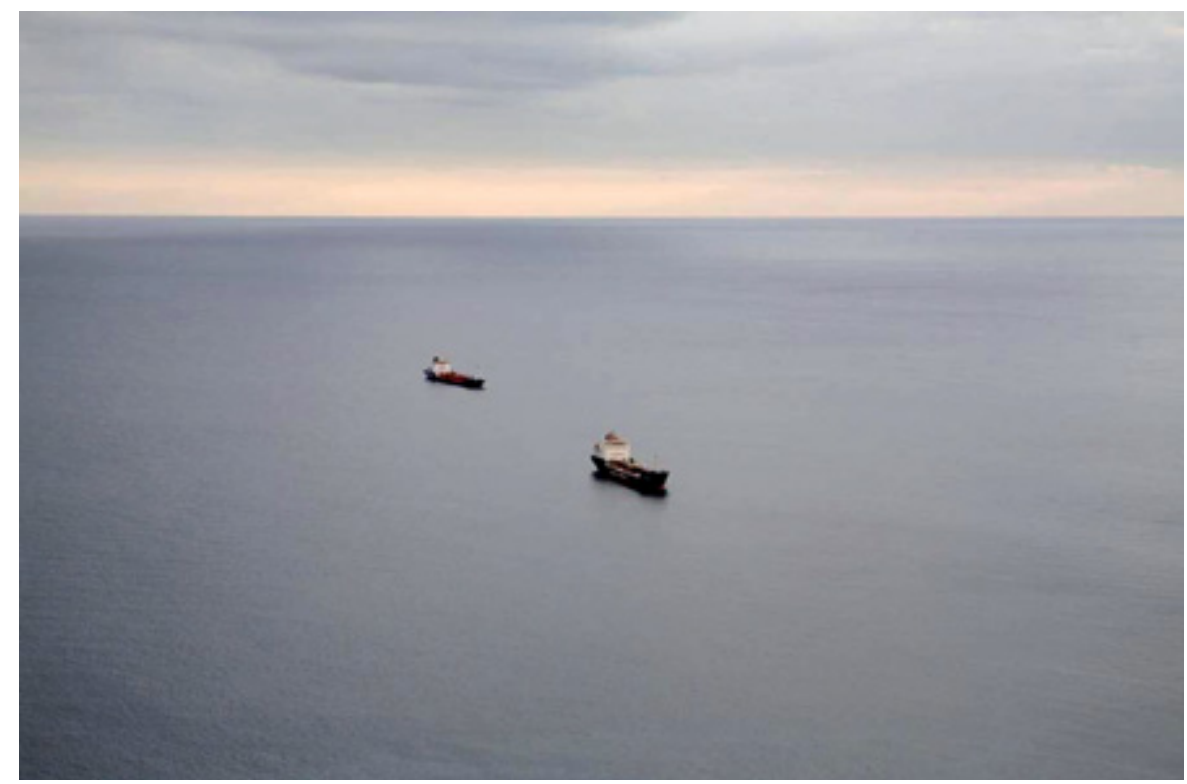

Fig. 3.

Adrián Alemán, Socius (2010).

clilladas junto a unos restos que emergen de la tierra, y ponen el acento en esa necesidad de memoria rescatada.

Por último, el fotógrafo herreño Alexis $\mathrm{W}$, en su última edición de la ventana indiscreta, interviene en el espacio público del madrileño barrio de Chueca con imágenes montadas sobre cajas de luces que, situadas en los balcones, invitan a la reflexión participando del acontecer urbano con su presencia. Construyen un diálogo entre los retratos de fusilados durante la guerra civil, en blanco y negro, y retratos de sus descendientes en color con los ojos vendados, incidiendo en tres aspectos que las imágenes quieren poner de manifiesto: la violencia que se pone en escena desde el presente haciendo actual la memoria de la pérdida dolorosa, por un lado, el gesto simbólico del olvido que se esconde tras los ojos tapados de los nietos de las víctimas, y un homenaje a la diosa de la justicia con los ojos vendados. Todos los personajes que recuerdan son mujeres, depositarias de la herencia de dolor de la guerra. Una de ellas, explica el autor, recita de memoria en el momento de la toma la carta que su padre le envió antes de ser fusilado y tardó veinte años en abrir (fig. 4).

En su ensayo Family frames, la pensadora estadounidense Marianne Hirsch presenta el concepto de "postmemoria". Partiendo de su experiencia personal, explora el trauma de persecución y el exilio de su propia familia y de todas las familias de judíos que huyeron durante la Segunda Guerra Mundial buscando refugio en América. Tomando como referencia las fotografías de su propio álbum de familia y partiendo de la necesidad de duelo que encierran las páginas de todo álbum con respecto a los protagonistas encerrados en sus páginas y sus historias vitales, personales e históricas, Hirsch identifica la memoria con los supervivientes del drama del Holocausto, y la "postmemoria" con los hijos de los supervivientes. Propone la idea de "postmemoria" en tanto que ejercicio de reconstrucción imaginativa de la experiencia vital: "postmemoria es una poderosa y muy particular forma de memoria precisamente porque su conexión con su objeto o fuente está mediatizada no a través de la recolección sino a través de una imaginativa implicación y creación" ${ }^{\text {20 }}$. En este sentido, Hirsch acude a una distinción similar a la que Reyes Mate hace entre historia y memoria, cuando

${ }^{20}$ Hirsch, 1997: 24.

Arch. esp. arte, LXXXIX, 354, ABRIL-JUNIO 2016, 153-166

ISSN: 0004-0428, eISSN: 1988-8511, doi: 10.3989/aearte.2016.10 


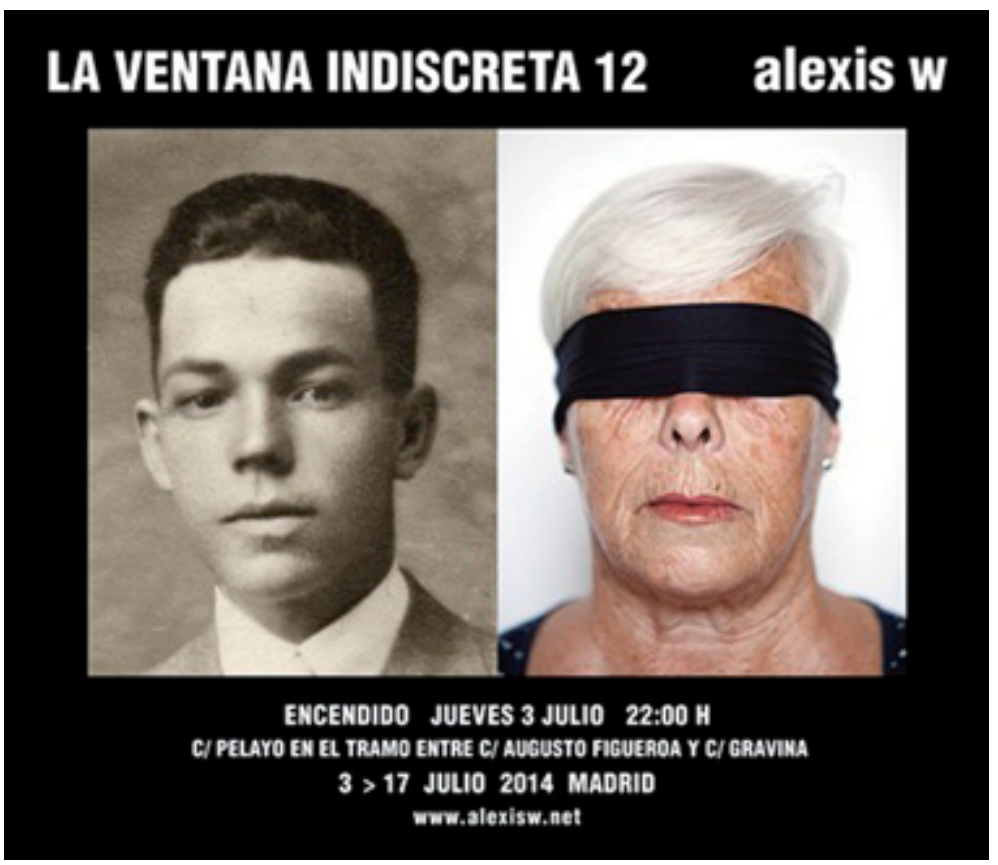

Fig. 4. Alexis W, Ventana indiscreta (2014).

afirma que "la historia (está) más centrada en la reconstrucción de los hechos y, la memoria en la construcción del sentido presente; la una trabaja con testimonios y la otra con archivos".

Huelga aclarar que ninguno de los fotógrafos citados más arriba pretende hacer historia, aunque su trabajo, formalmente hablando, tome prestado el registro del archivo en algunas ocasiones. En todos los casos se trata de un ejercicio creativo que pone el acento en las víctimas, a quienes devuelve su voz, su cuerpo y su identidad de seres humanos. "Re-pensar la verdad -aclara en este sentido Reyes Mate- significa no reducir realidad a facticidad, es decir, reconocer que forman parte de la realidad los sin-nombre, los no-sujetos, las víctimas y los vencidos de la historia" ${ }^{21}$. Tanto la ficción como el documento como vehículos de reflexión, son la herramienta que visualiza ese silencio al que hacíamos referencia, en el más amplio sentido de la palabra: silencio vital y silencio histórico.

Marianne Hirsch y Reyes Mate coinciden al señalar el salto generacional al que hacíamos alusión al comienzo de nuestro trabajo y donde se crea un ejercicio de transmisión entre nietos y abuelos que trata de dar respuesta a una necesidad de comprensión histórica. Al respecto escribe Hirsch:

Puede decirse que el motor de una imaginación ficcional está alimentado en buena parte por el deseo de conocer el mundo tal y como era y desapareció antes de nuestro nacimiento. Y todavía resulta mucho más ambivalente esta curiosidad para los hijos de los supervivientes del Holocausto, exilados de un mundo que ha dejado de existir y violentamente borrado. El suyo es un deseo diferente, tan poderoso como conflictivo: el deseo no sólo de sentir o de saber, sino también de re-memorar, de re-construir y de re-encarnar, de recolocar y de reparar. Para los supervivientes que han sido separados y exilados de un mundo devastado, la memoria es necesaria como un acto no sólo de llamada sino también de duelo, duelo con frecuencia temperado con ira, rabia y desesperación ${ }^{22}$.

\footnotetext{
${ }^{21}$ Mate, 2008: 176.

22 Mate, 2008: 242-43.
} 
Este mismo fenómeno interpretativo es el propuesto por otros trabajos como Album de la mexicana Ana Casas Broda, muy cerca en planteamientos y resolución formal, el de Hirsh desde la teoría y el Broda desde la práctica, pues el trabajo de Ana Casas Broda reflexiona y documenta igualmente el éxodo familiar huyendo de la persecución nazi. O la exposición The Silent Village, donde también desde el registro del archivo y la ficción, fotográfica y literaria, se recupera la memoria de la destrucción masiva y total del pueblo checo de Lidice en 1942 como represalia a un ataque de la guerrilla con un saldo de dos soldados muertos del ejército alemán. Este tipo de represalias tuvo lugar con bastante frecuencia también en la Francia ocupada buscando un doble objetivo: represaliar la agresión de los maquis, al tiempo que se aterrorizaba a la población civil con la intención de despertar la animadversión hacia la resistencia y suprimir de este modo cualquier tipo de ayuda que pudieran solicitar.

The Silent Village, al igual que el resto de fotógrafos aquí presentados, reflexiona sobre el papel de la fotografía y la literatura como testigos de traumas colectivos. Todos estos trabajos comparten una misma voluntad de re-construir, re-encarnar, recolocar y reparar desde el presente el silencio de la víctimas. "No se trata de hacer justicia - aclara Reyes Mata- sino de reconocer que sin memoria de la injusticia no hay manera de hablar de justicia" ${ }^{23}$. Tal vez, como señala H. Rosi Song, esa necesidad creciente y perentoria de recuperar una memoria vicaria se deba a "la falta de un marco oficial para las memorias privadas y sus huellas que explica la cantidad de objetos y en particular fotografías familiares que fomentan la creación de un archivo alternativo de la guerra civil española a medida que salen a la luz pública" ${ }^{\text {24 }}$. En este sentido, lo que puede observarse en la mayoría de estos trabajos fotográficos es la necesidad de escribir una historia con minúsculas y testimonial que con el paso de los años se diluye, como se lamenta Nexus 6 antes de morir, como lágrimas en la lluvia.

La secuencialización de la historia de la fotografía española del siglo XX queda estructurada en torno a los conceptos de Silencio, Olvido y Memoria. Se trata de tres respuestas estéticas diferentes ante un mismo acontecimiento traumático, condicionadas a su vez por las circunstancias históricas que a cada una de las generaciones les ha tocado vivir. Tanto el silencio, como el olvido, o como la necesidad de memoria son formas de supervivencia artística y vital, si es que la una pueda separarse de la otra.

Hablaron desde el silencio porque habían nacido y crecido en el silencio, y lo hicieron maravillosamente, hasta tal punto que la generación de fotógrafos que desarrolla su trabajo en los años cincuenta representa, en nuestra opinión, la edad de oro de la fotografía española. Aquellos que decidieron el olvido sintonizan a la perfección con el signo de su tiempo, el de la transición política hacia la democracia. Son los primeros artistas profesionales de la historia de la fotografía española, alcanzando una proyección internacional que nada tiene que envidiarle a la de cualquier artista plástico, perfectamente integrados, cada cual con sus matices y opciones creativas, en las corrientes estéticas dominantes desde los setenta hasta nuestros días.

La generación de la Memoria no reúne a todos los fotógrafos de ese momento, pero sí son los únicos en la historia fotográfica española del siglo XX que se han interesado y se han propuesto tomar el testigo de un legado que salta una generación y pide una respuesta al trauma colectivo de la guerra civil. Es aprogramática, y se encuentra desubicada entre la generación del Olvido, que apostó sin complejos por la internacionalización de sus ideas y de su estética, y los fotógrafos inmediatamente posteriores, que aspiran a triunfar por derecho propio y se abren camino en el mundo del arte ajenos por completo al marchamo de la guerra, sus huellas y la narración oral que perduró en los nietos de sus protagonistas. La generación de la Memoria funciona, en la historia de la foto-

\footnotetext{
${ }^{23}$ Mate, 2008: 169.

${ }^{24}$ Song, 2014: 372.
}

Arch. esp. arte, LXXXIX, 354, ABRIL-JUNIO 2016, 153-166

ISSN: 0004-0428, eISSN: 1988-8511, doi: 10.3989/aearte.2016.10 
grafía española, como una anomalía necesaria otorgando visibilidad a lo que Reyes Mata describe como "lo sin-nombre, lo que no ha llegado a ser, en una palabra, lo fracasado, lo expulsado a la insignificancia" 25 y dar así sentido y cuerpo a lo impensable. El silencio y el olvido fueron una herramienta para la supervivencia. También la generación de la Memoria recuerda para vivir.

\section{BIBLIOGRAFÍA}

Alba, Víctor (1980): Todos somos herederos de Franco, Barcelona: Planeta.

Alberruche Rico, Mar (2010): "Fotografía "pauperista" en la España franquista". En: Encuentro de críticos e investigadores, Centro Cultural de España en México, Trasatlántica, PhotoEspaña. México. En: <www.phedigital.com/portal/es/archivos> 10/06/2014.

Alemán, Adrián (2013): Socius. Gran Canaria: Centro Atlántico de Arte Moderno.

Aliaga, Juan Vicente (2011): Exercicis de memòria. Ejercicios de memoria. Exercices in Memory. Barcelona: Centre d'Art la Panera.

Bernad, Clemente (2011): Desvelados. Pamplona: Alkibla.

Casas Broda, Ana (2000): Álbum. Murcia: Mestizo.

Doctor Roncero, Rafael et all. (1995): Nueva Lente. Inicio y desarrollo de la fotografia de creación en España. Madrid: Dirección General de Patrimonio Cultural.

Domingo Martínez, Rosario (2013): La obra de arte como contradocumento. Representación de la memoria antiheroica como recurso en el arte contemporáneo. Tesis doctoral, Universidad Politécnica de Valencia.

Fernández, Horacio (2004): Variaciones en España. Fotografía y arte 1900-1980. Madrid: La Fábrica editorial.

Hirsch, Marianne (1997): Family Frames. Photography Narrative and Postmemory. Londres: Harvard University Press. Jennings, Humphrey/Finnemore, Peter/Trezise, Rachel/Ventura, Paolo (2010): The Silent Village. Wales: Ffotogallery. Llorens, Martí (1999): Memorias revolucionarias. Murcia: Mestizo.

López Mondejar, Publio (1997): Historia de la fotografía en España. Madrid: Lunwerg.

Mate, Reyes (2008): La Herencia del olvido. Madrid: Errata Naturae.

Mira, Enric (1991): La Vanguardia fotográfica de los años setenta en España. Alicante: Instituto de Cultura Juan Gil-Albert, Diputación Provincial de Alicante.

Moro, Sofía (2006): Ellos y nosotros. Barcelona: Blume.

Ortega, Ana Teresa (2010): Cartografias silenciadas. Valencia: Universidad de Valencia.

Pérez Esteban, Pedro / Giménez Corbatón, José (2006): Cambriles. Mas de las Matas, Grupo de Estudios Masinos.

Pérez Esteban, Pedro / Giménez Corbatón, José (2009): Morir al raso. Zaragoza: Gobierno de Aragón.

Pérez Esteban, Pedro / Giménez Corbatón, José (2011): Memoria difusa. Zaragoza: Gobierno de Aragón.

Ricoeur, Paul (2000): La Mémoire, l'histoire, l'oubli. París: Seuil.

Saura, Carlos/Sánchez Vidal, Agustín (2000): Carlos Saura fotógrafo. Madrid: Galaxia Gutemberg, Círculo de Lectores. Song, H. Rosi (2014): "Visual Fictions and the Archive of the Spanish Civil War". En: MLN, 129, No 2, pp. 367-390. Soto, M. (2006): Archivos de Archivos, 1998-2006. Barcelona: Centre d'Art la Panera.

Sougez, Marie-Loup (2011): Historia de la fotografia. Madrid: Cátedra.

Sougez, Marie-Loup (coord.) (2007): Historia general de la fotografía. Madrid: Cátedra.

Terré Alonso, Laura (2006): Historia del grupo fotográfico AFAL 1956/1963. Sevilla: Photovisión.

Torres, Frances (2007): Dark is the Room Where We Sleep. Oscura es la habitación donde dormimos. Barcelona: Actar.

Fecha de recepción: 03-IX-2014

Fecha de aceptación: 15-XII-2014

\footnotetext{
${ }^{25}$ Mate, 2008: 164.
} 